EDITORIAL

\title{
SCIENTIFIC INNOVATION FOR A SUSTAINABLE DEVELOPMENT OF AFRICAN AGRICULTURE
}

\author{
Marc Heijde \\ International Plant Biotechnology Outreach, VIB, Ghent University, Belgium
}

On August 30-3I, 20I8, a two-day symposium took place in Ghent (Belgium) with the aim of deliberating on scientific innovation for the development of a sustainable agriculture in Africa. This symposium was attended by African and European scientists, representing both the public and private sectors. Topics included relevant crops for Africa, soil quality, biotic and abiotic stresses, and human and animal health; and were all handled in light of a critical assessment of how research and scientific innovation could tackle the challenges encountered in crop production.

Currently, the African continent is unable to meet the exponentially increasing demand for food and feed that is the consequence of a fast-growing population (from I.2 billion in 2019 to 2.4 billion by 2050), a rising middle class and a mainly urban population eager to consume more protein-rich food. The green revolution starting in the I950s has allowed the intensification of food production in many regions. In this way, a level of food security was ensured on our planet that had never been reached previously, although not without being criticized because of its significant environmental footprint. However, Africa has not reaped the benefits of this revolution, leaving its agriculture with minimalyielding crops, poor soils, and a low level of mechanization.

Development of a sustainable agriculture that could provide high-quality food for the population is often attempted with two different mindsets. These approaches, as presented by Charles Mann in his book "The wizard and the prophet" (2018) are on the one hand the "wizard" approach, represented by Norman Borlaug and on the other the "prophet" approach, represented by William Vogt. Norman Borlaug (I9I4-2009) is known as the father of the green revolution, whose work allowed a substantial increase in agricultural production while William Vogt (I902-I968) is remembered as a pioneer in environmentalism. Brought to the extreme, in the first technological approach, the scientist tries to overcome the Earth's limits by generating high-performing crops for more yield, whereas the other approach will focus on the idea that humans need to accept nature's limits. As is often the case, solutions might have to be found somewhere in the middle, if sustainable agricultural development is to sit alongside an increase in 
qualitative and quantitative food demand. Humans have been playing the wizard for thousands of years, transforming wild plants, such as teosinte, into today's maize that grows in fields all over the planet. The breeding of improved crops and the search for technical solutions have been a constant endeavor to assess new agricultural threats or limitations, issues abandoned by farmers to scientists.

Today, the technological effort to ameliorate varieties and farming practices is unprecedented and highly complex, making it more difficult for the consumers to understand and to accept how our food is produced, a problem exemplified by the latest breeding techniques, such as genome editing. With this technology it is now possible to precisely modify the DNA of a plant to improve its agronomic traits or nutritional quality. For many people, this approach is seen as a step too far in "wizardry" and, hence, problematic in terms of approval. Nevertheless, no clear and rational arguments can defend this reluctance until now. This apprehension does not uniquely occur in agriculture and has been experienced for many technological developments, whereas other technologies, such smartphones, have been rapidly and highly adopted, regardless of the potential health risks. This acceptance fear has been very well exemplified by Calestous Juma (1953-2017) in his book "Innovation and its Enemies: Why People Resist New Technologies". Adoption of a technology is finally about measuring the risks it might bring and balancing them with the potential benefits. In conclusion, multiple challenges exist to obtain a sustainable agriculture in Africa that can feed its population with sufficient and nutritious food. Therefore, it is not only crop improvement that is needed, but also real progress all along the food value chain up to the consumer. In this special issue, a selection of aspects discussed during the symposium are developed into a series of articles, demonstrating what science, without focus on one particular technology or innovation, can bring to sustainable agricultural development.

\section{References}

Borlaug, C. (2000). The green revolution revisited and the road ahead. (https://www.nobelprize.org/ uploads/2018/06/borlaug-lecture.pdf).

Juma, C. (2016). Innovation and Its Enemies: Why People Resist New Technologies. New York, Oxford University Press; 4I6 p. [ISBN 9780190467036].

Mann, C. (2018). The Wizard and the Prophet: Two Groundbreaking Scientists and their Conflicting Visions of the Future of our Planet. London, Picador, 616 p. [ISBN 9781509884I62]

Vogt, W. (1948). Road to Survival. New York, W. Sloane Associates, 335 p. [ISBN 0548385i65] 